\title{
Spatiotemporal Distribution of Non-syndromic Orofacial Clefts in Villa Clara Province, Cuba, 2013-2018
}

\author{
Noel Taboada-Lugo MD MS, Manuela Herrera-Martínez MD PhD, Geni Hernández-González MD, Hartley Ledesma-Hernández
}

\begin{abstract}
INTRODUCTION To discern environmental factors that, along with genes influencing susceptibility, drive the occurrence of nonsyndromic congenital disorders, it is important to identify clusters of these abnormalities.
\end{abstract}

OBJECTIVE Determine the adjusted prevalence of orofacial clefts in Villa Clara Province, Cuba, and identify and describe their spatiotemporal variability during January 2013-December 2018.

METHODS Cases were selected from a total of 46,007 births that took place in the province's four maternity hospitals during the study period. Of these, 36 cases of newborns with either prenatal or postnatal nonsyndromic orofacial cleft diagnoses were obtained from hospital and community registries. We applied spatial statistical analysis techniques with the aim of identifying areas within the province with the highest prevalence.

\section{INTRODUCTION}

Non-syndromic orofacial cleft (NSOFC) refers to a congenital abnormality of multifactorial origin attributed to a combination of genetic and environmental factors, in which a monogenic or chromosomal cause has not been identified, characterized by a cleft lip with or without palate involvement. Its Online Mendelian Inheritance in Man (OMIM) designation is 119530.[1-3]

NSOFC results when structures that give rise to the upper lip and secondary bone palate fail to fuse during fetal development. Its clinical phenotype varies from small abnormalities on the vermillion border of the lip (bilaterally, unilaterally or centrally) to large spreading clefts reaching toward the nostril floor through the maxilla's alveolar portion, which can cause complete palatal clefts encompassing the secondary or posterior palate, extending over the entire soft palate and reaching the anterior incisive fossa.[4,5]

In 1942, Fogh-Anderson classified NSOFCs as cleft lip with cleft palate $(C L$ with $C P)$, cleft palate $(C P)$ and cleft lip $(C L)$. Early in the 21st century, NSOFCs were already being classified into two groups: either $\mathrm{CL}$, with or without non-syndromic $\mathrm{CP}$; or non-syndromic $\mathrm{CP}$ according to different embryological and environmental factors and genetic studies. The CL group with or without non-syndromic $\mathrm{CP}$ includes both persons with $\mathrm{CL}$ only (unilateral or bilateral) and those with CL accompanied by CP. Cases with non-syndromic CP show a separation in either the hard palate, soft palate or uvula

\section{IMPORTANCE}

Detecting spatio-temporal orofacial cleft clusters allows the planning of more targeted investigations aimed at identifying genetic, epigenetic, or environmental factors related to the origin of these congenital abnormalities.
RESULTS Adjusted prevalence was 0.78 per 1000 births. The most common non-syndromic orofacial congenital abnormality was cleft lip with or without cleft palate. Frequency of congenital abnormalities increased during the first two years of the study and decreased during the last two years. A primary spatiotemporal cluster was identified in two contiguous municipalities in 2017 and a secondary one in two other neighboring municipalities between 2014 and 2016.

CONCLUSIONS Spatiotemporal analysis of non-syndromic orofacial clefts in Villa Clara Province, Cuba, identified two spatiotemporal clusters, constituting an opportunity to better understand the etiology of orofacial clefts.

KEYWORDS Cleft lip, cleft palate, congenital abnormalities, disease hotspot, spatial analysis, Cuba

without lip involvement, pointing to the highly variable phenotypic expression of this kind of congenital abnormality. $[1,2,6]$

The most serious morphological abnormality among NSOFCs is bilateral CL and total CP (10\% of cases) and the most frequent is unilateral CL with total CP (40\%). Syndromic abnormalities have dysmorphic patterns which are associated with other congenital abnormalities; more than 300 different syndromes associated with NSOFCs have been identified. However, most cases present as non-syndromic abnormalities (70\%).[7-10]

Although practically all types of Mendelian inheritance have been considered for these congenital abnormalities, many of their characteristics are those of a classic multifactorial threshold trait, where complex interactions between genetic and environmental factors influence phenotypes. Evidence of genetic contributions to phenotypic expression are supported, for example, by variations in frequency between ethnic groups, an increased risk of recurrence of the most severe phenotypes within families (from $4.0 \%$ in unilateral CL without CP to $8.0 \%$ in cases with both $C L$ and bilateral $\mathrm{CP}$ ), a greater concordance between monozygotic or identical twins $(25 \%-40 \%)$ than between dizygotic or fraternal twins $(3 \%-6 \%)$, a greater risk of recurrence in first-degree relatives and a $76 \%$ heritability rate. $[1,7]$

On the other hand, various environmental risk factors have been identified in NSOFC etiology, many of which are both preventable and tend to vary depending on the specific congenital defect. Among these are maternal alcohol consumption, habitual smoking, maternal comorbidities like diabetes and obesity, use of certain medications, exposure to environmental pollutants and pesticides, and deficiencies in folic acid and other micronutrients in the first trimester.[1,2,11-15]

The consideration of space is implicit when calculating incidence and prevalence rates. Statistical techniques for detecting spa- 
tial, temporal or spatiotemporal clusters provide opportunities to quantify aspects related to the abnormalities' spatial and temporal distributions. Variability patterns in the timing and geographic distribution of health events are essential for understanding exposure and preventing future events, whether the underlying process is contagious, environmental or related to genotypic variability.

Information about spatial patterns is just as useful as information about demographic or temporal patterns, allowing deeper exploration of the interactions among people, time and space.[16]

Villa Clara Province is in central Cuba, and at $8411.81 \mathrm{~km}^{2}$ is the fourth-largest Cuban province, representing $7.6 \%$ of the country's total landmass. It is divided into 13 municipalities and has a population of 780,749 . From January 2013 through December 2018, a total of 46,007 births occurred in the province.[17]

Malformations involving orofacial structures account for threequarters of all congenital abnormalities, which can be attributed to the intricate genetic and epigenetic mechanisms involved in assembling the orofacial region.[18,19] NSOFCs affect approximately 135,000 newborns annually worldwide, with prevalence ranging from 1 in 2500 to 1 in 500 births. Average prevalence worldwide is 1 in 700 newborns, although there is considerable geographic, ethnic and sociocultural variation.[6,7,8,20,21]

The most commonly-treated congenital abnormalities in Cuban pediatric maxillofacial surgery services are labial and palatal fissures.[22,23] Herrera,[24] in a 2009-2013 cohort study of congenital malformations and cognitive disability in Villa Clara Province, found a frequency of 1 in 1115 newborns, with an adjusted prevalence of 1.7 per 1000 births.

There are no studies analyzing the spatiotemporal variability of these congenital disorders in Cuba. Our research was carried out to determine the adjusted prevalence of NSOFCs in Villa Clara Province, and identify and describe their spatiotemporal variability in the years 2013-2018.

\section{METHODS}

Study type We carried out a retrospective descriptive observational study using data from 2013-2018 obtained from the Cuban Congenital Malformation Registry (RECUMAC) and the Cuban Congenital Malformation Prenatal Registry (RECUPREMAC). Both RECUMAC and RECUPREMAC are hospital-based registries in operation since 1985, allowing for clinical and epidemiological surveillance of congenital abnormalities in Cuba. These registries include all live newborns, stillbirths and elective abortions after 20 weeks' gestation, weighing $\geq 500$ grams who presented with one or more major congenital abnormalities upon physical examination during the first few hours after delivery.

Data collection RECUMAC data were compiled using results of physical and dysmorphological examinations performed at one month and three months of age by genetic counselors as part of the National Program for the Diagnosis, Management and Prevention of Genetic Diseases and Congenital Disorders. This program was first implemented in the 1980s and provides community-based information from all medical genetics departments in all Cuban municipalities.[25]

Congenital abnormalities were coded according to the ICD-10. [26] All cases with syndromic NSOFC were excluded from the study. In all cases, diagnosis was confirmed by clinical genetics specialists at the Villa Clara Provincial Medical Genetics Center.

Statistical analysis Prevalence rates adjusted at birth were calculated by dividing the numerator (NSOFC live births, stillbirths or elective terminations among 2013-2018) by the denominator (total live births and stillbirths in the same period). Prevalence rates were expressed as the number of cases per 1000 births. Adjusted prevalence rates were calculated for each of the spatial analysis units (municipalities) based on the number of births (live or stillbirths) that occurred in each municipality during the study period. Temporal units of analysis were divided by year.

To detect spatiotemporal NSOFC clusters, we used specific statistical techniques for spatiotemporal analysis available in the freeware SaTScanv7.01. Probability of clusters in each spatial analysis unit was compared with the probability of clusters occurring outside the unit, and we estimated maximum likelihood ratios using the Kulldorff method[27] to check if the number of cases observed in each municipality exceeded the number of cases that would have been expected for the year. Areas with statistically significant maximum values were considered primary clusters, where case frequency could not be attributed to chance. In all other cases, they were considered secondary clusters. We set the significance level at $\alpha=0.005$.

Expected case number in each municipality was calculated using the following expression:

$$
E(c)=p \times C / P
$$

...where $c$ is the observed number of NSOFC cases in each spatial unit; $p$ is the reference population (live births, stillbirths, and elective pregnancy terminations) in each municipality; and $C$ and $\mathrm{P}$ correspond to the total number of NSOFC and births (live births and stillbirths), respectively.

Relative risk (RR) for each spatial unit was calculated by dividing the observed number of cases by the expected number of cases, using the following formula:

$$
R R=\frac{c / E(c)}{(C-c) /[C-E(c)]}
$$

...where $\mathrm{c}$ is the observed number of NSOFC cases, $\mathrm{E}$ is the expected number of cases, and $C$ is the total number of cases within the cluster.[28] Cartographic representations were made using Maplnfo v. 8.5 by exporting statistical results to the program's geographic information system. Primary and secondary clusters were represented via red-to-pink color degradation.

Ethics This study is based on data analysis of records from which all identifying information had been removed, guaranteeing complete patient anonymity. Additionally, all mothers of newborns (live births and stillbirths) included in the study gave written informed consent, in accordance with the Helsinki Declaration's ethical standards for human research.[29,30] The study was approved by the Ethics Committee of Villa Clara Medical University's Biomedical Research Unit, as part of the project entitled Interrelation of genetic and environmental factors in con- 
genital malformations with probable association to folic acid and other micronutrient deficiencies in Villa Clara Province.

\section{RESULTS}

A total of 36 NSOFC cases were registered and included in this study from January 2013 through December 2018. Live births accounted for $30(83.3 \%)$ of congenital abnormalities and 6 $(16.7 \%)$ were elective pregnancy terminations (in all cases, combined with cardiovascular congenital abnormalities, without evidence of underlying syndromic etiology). No NSOFC were observed in stillbirths. Other congenital abnormalities were observed in 8 cases $(22.2 \%)$. CL with or without CP was observed in 28 cases $(77.8 \%)$ (Figure 1$)$.

There were 46,007 births during the study period (45,692 live births and 315 stillbirths), for an adjusted NSOFC prevalence of 0.78 per 1000 births, and an overall prevalence of 1 per 1277 newborns (Table 1). In general, NSOFC prevalence increased until 2016 and then decreased between 2016 and 2018 in cases of CL with or without $\mathrm{CP}$, while adjusted prevalence of non-syndromic CP varied little, save for two peaks in the curve in 2014 and 2016 (Figure 2).

Figure 1: NSOFC relative frequency, Villa Clara Province, Cuba, 2013-2018

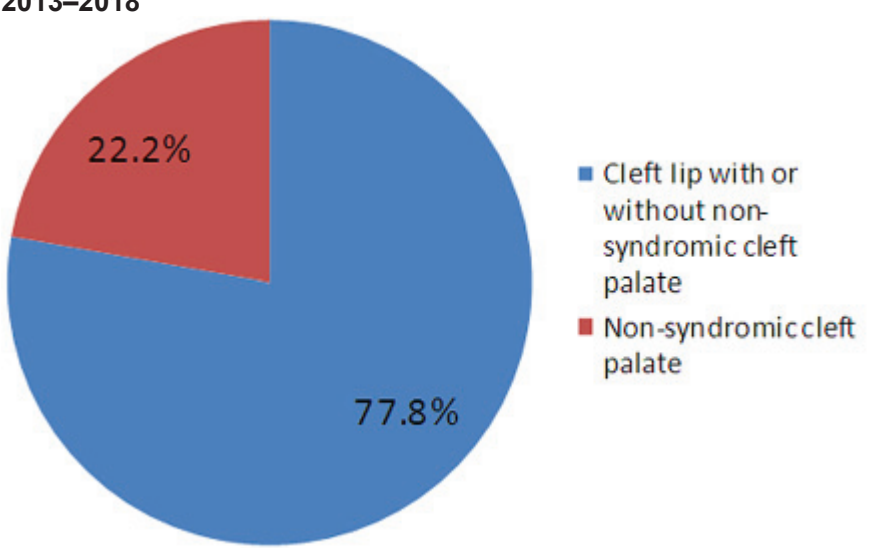

NSOFC: Non-syndromic orofacial clefts

Table 1: Adjusted NSOFC rates, Villa Clara Province, Cuba, 2013-2018

\begin{tabular}{|c|c|c|c|}
\hline $\begin{array}{l}\text { Congenital } \\
\text { abnormality }\end{array}$ & Cases & $\begin{array}{l}\text { Adjusted } \\
\text { prevalence per } \\
1000 \text { births }\end{array}$ & ICD-10 codes \\
\hline $\begin{array}{l}C L \text { with or } \\
\text { without } C P\end{array}$ & 28 & 0.61 & $\begin{array}{l}\text { Q36, Q36.0, Q36.1, } \\
\text { Q36.9, Q37, Q37.0, } \\
\text { Q37.1, Q37.2, } \\
\text { Q37.3, Q37.4, } \\
\text { Q37.5, Q37.8, Q37.9 }\end{array}$ \\
\hline Non-syndromic CP & 8 & 0.17 & $\begin{array}{l}\text { Q35, Q35.1, Q35.3, } \\
\text { Q35.5, Q35.9 }\end{array}$ \\
\hline Total NSOFC & 36 & 0.78 & $\begin{array}{l}\text { Q35-Q37 (except } \\
\text { Q35.7: bifid uvula) }\end{array}$ \\
\hline
\end{tabular}

CL: cleft lip CP: cleft palate ICD-10[26] NSOFC: Non-syndromic orofacial cleft

Both primary and secondary spatiotemporal NSOFC clusters were observed in Villa Clara from 2014 through 2016 (Figure 3), and we collected information on these clusters (municipalities, observed and expected case numbers, statistical analysis results related to relative risk, $p$-values) (Table 2 ).
Figure 2: Annual adjusted NSOFC prevalence, Villa Clara Province, Cuba, 2013-2018

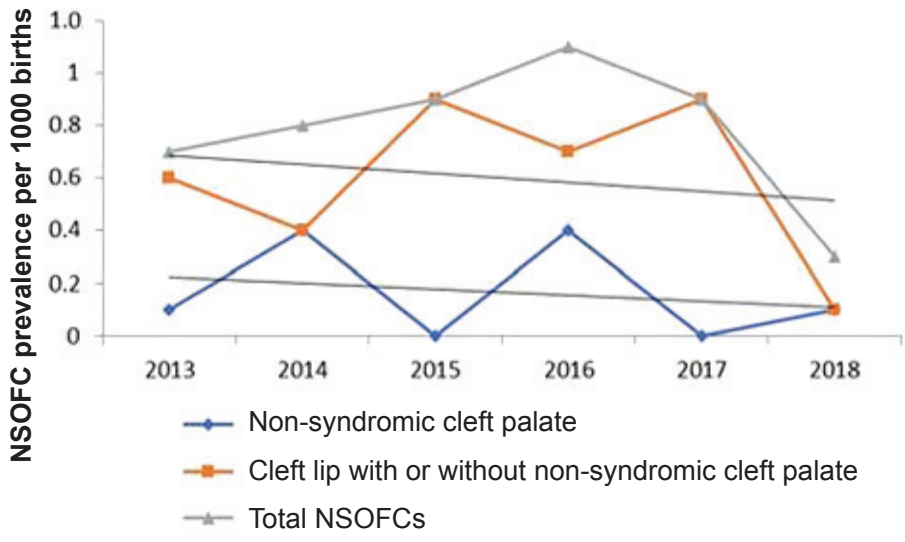

NSOFC: Non-syndromic orofacial clefts

\section{DISCUSSION}

Other associated congenital abnormalities were observed in 8 $(22.2 \%)$ NSOFC cases. Congenital heart disease (CHD) was the most common. In six of these infants, the abnormalities were detected in utero and the couple requested termination. Prenatal fetal health monitoring provides information necessary for detecting congenital abnormalities and in estimating their effects on postnatal life.[31]

CHD frequency in our study coincides with that observed by Jamalian in their work in Iran, who found that CHD, at 38\%, was the most frequent congenital abnormality co-occurring with orofacial clefts, while CHD was only observed in $2 \%$ of cases without orofacial clefts.[32]

However, a 22-year longitudinal hospital-based series carried out in the Manzanillo municipality (Granma Province, Cuba) found that the congenital abnormalities most frequently associated with lip-palatal clefts were those of the osteomyoarticular system (5.4\%), followed by CHD (3.9\%).[33]

$\mathrm{CL}$ frequency with or without non-syndromic $\mathrm{CP}$ in the present study $(77.8 \%$ of cases) was 3.5 times higher than that of nonsyndromic CP, similar to rates observed in Brazil $(78.6 \%$ of cases, 2.6 times the frequency).[2] Aggregate data from 9 South American countries in the Latin American Collaborative Congenital Malformation Study (ECLAMC) found CL frequency with or without non-syndromic CP ( $82.7 \%$ of cases) to be 4.7 times higher than non-syndromic CP.[20]

In Villa Clara Province, CL case frequency, with or without CP, was higher than rates in the eastern province of Santiago de Cuba from 2000 to 2009 (71.4\% of cases, 2.5 times higher than CP frequency).[34] A US population-based study conducted from 1989 to 2010 in 8 California counties found an overall frequency of $\mathrm{CL}$ with or without CP of $65 \%, 1.9$ times higher than the frequency of isolated CP, although this study was limited by its failure to include stillbirths or elective terminations.[35]

As CP is less evident upon external examination, non-syndromic $\mathrm{CP}$ prevalence could be underestimated in studies basing their data on initial newborn inspection.[8] However, this is unlikely to be the case in our study, as all live births are evaluated before dis- 
Table 2: Spatiotemporal NSOFC rates, Villa Clara Province, Cuba, 2013-2018

\begin{tabular}{|l|l|r|r|r|r|r|}
\hline Cluster & \multicolumn{1}{|c|}{ Municipality } & Years & $\begin{array}{c}\text { Observed } \\
\text { cases }\end{array}$ & $\begin{array}{c}\text { Expected } \\
\text { cases }\end{array}$ & RR & p-value \\
\hline Primary & $\begin{array}{l}\text { Corralillo, } \\
\text { Quemado de Güines }\end{array}$ & 2017 & 5 & 0.31 & 18.93 & 0.004 \\
\hline Secondary & Cifuentes, Encrucijada & $2014-2016$ & 4 & 1.28 & 3.41 & 0.965 \\
\hline
\end{tabular}

NSOFC: Non-syndromic orofacial cleft RR: Relative risk

Figure 3: Spatiotemporal NSOFC clusters, Villa Clara Province, Cuba, 2013-2018

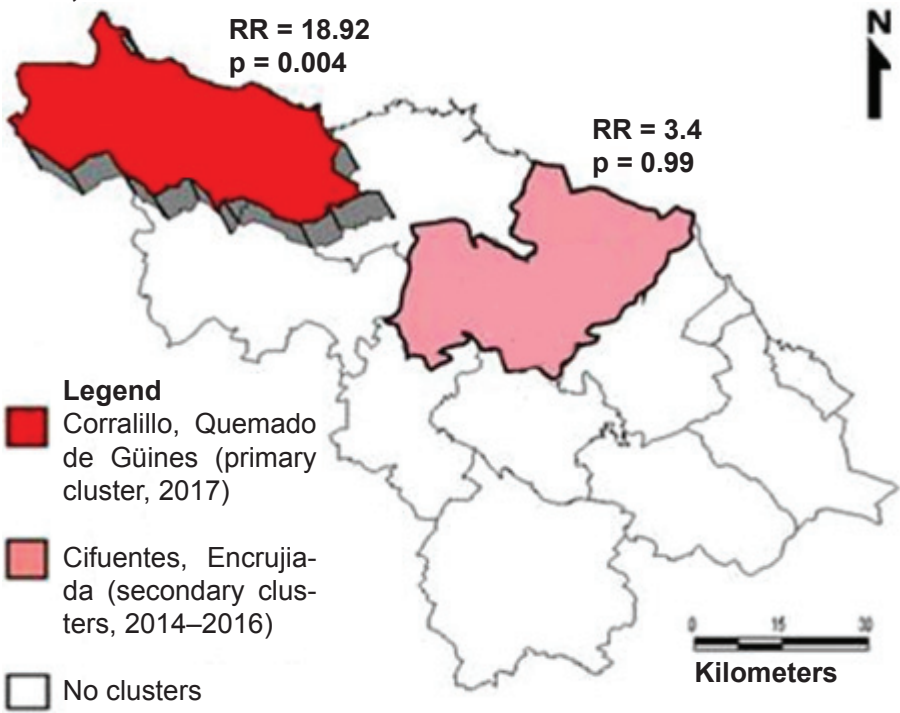

charge in neonatology services, at one month and three months of life in community genetics services, and all elective pregnancy terminations are carried out at the provincial maternity hospital, where all fetuses undergo an exhaustive morphological study by pathology services.

In several national and international studies, isolated CP represents only a third to a half of all observed NSOFC cases. $[8,24,34,36]$ Other studies show even lower frequencies, including one carried out in Villa Clara Province in the 1990s at the José L. Miranda Pediatric University Hospital's orthodontic service, where isolated CP represented only $11.4 \%$ of all NSOFC cases.[37]

One possible explanation for this difference is that hard-palate fissures are frequently accompanied by fissures in the lips.[8] Additionally, the lip and palate have different embryological origins: the palate is derived from the endodermal lamina, while the lips are derived from the ectodermal lamina.[2]

Adjusted NSOFC prevalence at birth in Villa Clara Province (0.78 per 1000 births) is within the range described both in Cuba and worldwide (0.7-1.5 per 1000 newborns).[2,22,29] This frequency is slightly higher than that found in research on congenital disorders in newborns carried out in Havana from 2000 to 2003, in which CL with or without CP NSOFC represented $5.4 \%$ of all isolated congenital abnormalities, at a prevalence of 0.71 per 1000 births.[38] This coincides with that observed by Cisneros in Santiago de Cuba, who diagnosed 98 NSOFC cases in 138,381 births over a period of 10 years.[34]
However, over a five-year period (20072011), researchers in Havana found an adjusted $\mathrm{CL}$ (with or without $\mathrm{CP}$ ) prevalence rate of 1.1 per 1000 births in Arroyo Naranjo municipality,[39] lower than observed frequencies in the years 1998 and 2000 in Octavio de la Concepción de la Pedraja Pediatric University Hospital in Holguín, a province in eastern Cuba, at 1.22 and 1.26 per 1000 live births, respectively.[40]

Frequency of congenital malformations varies greatly by ethnicity: populations of African ancestry have the lowest prevalence, followed by those of European descent, and then populations of Native American and Asian ancestry, who have the highest prevalence. $[6-8,10]$

A descriptive analysis using ECLAMC clinical-epidemiological data from 9 South American countries for 1995-2012, identified 2773 newborns with NSOFC (2293 with CL with or without CP, and 480 with isolated cleft palate), for an overall prevalence of 1.08 per 1000 newborns.[20]

In Guadalajara, Mexico, which has a large indigenous population, a 2009-2016 study found a high prevalence of NSOFCs (2.79 per 1000).[41] Other authors studying NSOFC rates in Mexico have estimated overall frequencies between 0.6-0.9 per 1000 live births.[28] In the USA, NSOFC rates vary considerably among different ethnic groups, with higher frequencies among Asian Americans and Native Americans (2 per 1000), followed by nonHispanic whites and Hispanics (1-1.43 per 1000), and with lowest frequencies among African Americans (0.4 per 1000).[7]

In addition to genetic factors that influence NSOFC-frequency differences among ethnic groups, economic and sociocultural factors play a role in NSOFC spatial variation. For example, NSOFC rates vary within ethnic groups and nationalities in Africa, from 0.5 per 1000 in Ghana and Nigeria (the latter the most populous African country and the nation with the largest Black population worldwide, at >160 million people); 0.7 per 1000 in Malawi; 1.4 per 1000 in Ethiopia; and up to 1.65 per 1000 in Kenya.[21,42]

A recent meta-analysis estimated NSOFC prevalence at 1.38 per 1000 births in low- and middle-income countries.[35] Risk factors are often interrelated; for example, Chileans with higher NSOFC rates are in the lowest socioeconomic strata and are also more likely to be of indigenous ancestry.[5] Possible explanations for differences in prevalence among geographic regions and socioeconomic statuses include environmental factors like vitamin intake, nutrition, access to health care and education and lifestyle-related factors, like smoking and alcohol abuse.[36,43] The decrease in cases after 2016 in our study could be attributed, in part, to increasing consumption of folic acid. In mid-2015, Villa Clara province implemented a program promoting preconceptive use of folic acid supplements in all women of childbearing age.

Spatiotemporal variability analysis using spatial epidemiology techniques can offer important clues as to environmental disease etiologies. Numerous geospatial cluster studies have been conducted examining the effect of environmental factors on different congenital abnormalities.[16,20,28] 
A primary spatiotemporal NSOFC cluster was identified in two municipalities in the extreme northwest corner of Villa Clara Province in 2017. Secondary spatiotemporal clusters were observed in the northern municipalities of Cifuentes and Encrucijada between 2013 and 2016, which merits further study.

These findings are similar to others that have identified geospatial variations for this type of congenital abnormality. For example, there are significant differences in NSOFC prevalence in different regions of China, with higher prevalence in the country's interior (frequencies of 3.0-4.7 per 1000) compared to coastal areas (at frequencies of 0.98-1.29 per 1000).

Researchers believe that environmental pollution, economic conditions, health service coverage and diagnostic capacity could contribute to geographic variation.[8] Even within the same Chinese province, great spatial variability has been reported; as an example, NSOFC prevalence in Jiayuguan (3.9 per 1000) and Dingxi (2.71 per 1000) were higher than other cities in Gansu Province. In that case, researchers did not observe significant correlations between economic conditions and NSOFC prevalence.[44]

Descriptive analysis of high NSOFC prevalence in South America found a spatial NSOFC cluster encompassing two cities in southern Ecuador (Cañar and Azogues). Different genetic and environmental risk factors were associated with NSOFCs in this area, including advanced maternal and paternal age, parental consanguinity, low maternal education level and use of drugs such as antimicrobials in the first trimester of pregnancy.[20]

Other NSOFC risk factors are low serum zinc concentrations and inadequate maternal levels of folic acid and other vitamins. In fact, according to $\mathrm{WHO}, 94 \%$ of congenital abnormalities occur in developing countries, where mothers are more vulnerable to malnutrition. In particular, micronutrients have a decisive influence on the health of pregnant women and normal fetal and placental development.[15,45,46] Zinc is an important micronutrient in embryo-fetal development and zinc deficiency is linked to nonsyndromic CP and other congenital abnormalities in animal studies.[21]

An exploratory ecological study of NSOFC spatial variability in the metropolitan area of Monterrey, Mexico, showed a marked concentration of cases in the urban periphery that resulted in several spatial clusters in the northeast territory showing a strong spatiotemporal association with environmental pollution.[28]
Although NSOFC spatiotemporal analyses do not offer causal explanations for identified clusters, they often generate working hypotheses that can be tested in future research. More targeted research designs, such as population-based case-control studies, should be used to explore potential causes of NSOFC clusters in Villa Clara Province. This study lays the foundation for future studies of specific NSOFC risk factors, including alcoholic beverage consumption; smoking; nutritional disorders, including deficiencies in zinc, folic acid, or other micronutrients; and heavy metal and nitrate levels in the soil and in drinking water in the territories under study.

Identifying NSOFC causal factors is the first step to NSOFC primary prevention. This study's strength is the high reliability and coverage level of the Cuban prenatal and postnatal records of congenital abnormalities, as well as absence of unregistered NSOFCs due to the network of community genetics services located in every municipality, whose counselors evaluate all newborns at one and three months of age. This study's limitations are similar to those of all spatial analysis research, including biases related to extrapolating aggregate-level associations to the individual scale, as well as expected limitations of spatiotemporal analyses, namely the inability to provide causal explanations for the study's results.

\section{CONCLUSIONS}

NSOFC frequency in Villa Clara Province, Cuba from 2013-2018 fell within expected Cuban and worldwide prevalence ranges. NSOFCs increased during the first four years of the study and began decreasing in 2016. Our research identified primary and secondary spatiotemporal NSOFC clusters in several geographically close municipalities. Although the underlying cause of this clustering remains unknown, identification of these clusters allows for more targeted investigations aimed at pinpointing factors related to NSOFC etiology.

\section{ACKNOWLEDGMENTS}

The authors thank Dr Gisela Noche and Dr Ana E. Algora from the Villa Clara Provincial Medical Genetics Center for their assistance in obtaining RECUMAC and RECUPREMAC data, respectively. We also thank the genetics counselors of Villa Clara Province's 13 municipalities, who assess all newborns at one month and three months of age in primary healthcare centers and contribute to the countrywide congenital abnormality registry. $-1 /$ -

\section{REFERENCES}

1. Mai CT, Cassell $\mathrm{CH}$, Meyer RE, Isenburg J, Canfield MA, Rickard R, et al. Brief report birth defects data from population-based birth defects surveillance programs in the United States, 2007 to 2011: Highlighting Orofacial Clefts. Birth Defects Res A Clin Mol Teratol [Internet]. 2014 Nov [cited 2020 May 2];100(11):895-904. Available at: https://www.ncbi.nlm.nih.gov/pmc/arti cles/PMC4631395/

2. Bezerra JF, Oliveira GHM, Soares CD, Cardoso ML, Ururahy MAG, Neto FPF, et al. Genetic and non-genetic factors that increase the risk of nonsyndromic cleft lip and/or palate development. Oral Dis [Internet]. 2015 Apr [cited 2020 May 2];21(3):393-9. Available at: http://onlinelibrary .wiley.com/doi/10.1111/odi.12292/full

3. Hamosh A, Scott AF, Amberger J, Valle D, McKusik MA. Online Mendelian Inheritance in Man (OMIM). Hum Mutat [Internet]. 2000 [cited
2020 May 2];15(1):57-61. Available at: https:// doi.org/10.1002/(SICI)1098-1004(200001) 15:1\%3C57::AID-HUMU12\%3E3.0.CO;2-G

4. More KL, Persaud TVN. Labio leporino y paladar hendido. In: Embriología Clínica. 8th ed. Barcelona: Elsevier; 2011. p. 188-96. Spanish.

5. Rincón RJ, Suazo J, Blanco R. Análisis molecular de Sonic hedgehog $(\mathrm{SHH})$ en la etiología de la fisura labio palatina no sindrómica en tríos casoprogenitores chilenos. Rev Fac Odontol Univ Antioq. 2012;24(1):110-20. Spanish.

6. Jia Z, Leslie EJ, Cooper ME, Butali A, Standley $\mathrm{J}$, Rigdon J, et al. Replication of 13q31.1 association in nonsyndromic cleft lip with cleft palate in Europeans. Am J Med Genet Part A [Internet] 2015 May [cited 2020 May 2];167(5):1054-60 Available at: http://onlinelibrary.wiley.com/doi/10 .1002/ajmg.a.36912/pdf
7. Cvjetkovic N, Maili L, Weymouth KS, Hashmi SS, Mulliken JB, Topczewski J, et al. Regulatory variant in FZD6 gene contributes to nonsyndromic cleft lip and palate in an African-American family. Mol Genet Genomic Med [Internet]. 2015 [cited 2020 May 2];3(5):440-51. Available at: https:// onlinelibrary.wiley.com/doi/10.1002/mgg3.155

8. Fan D, Wu S, Liu L, Xia Q, Tian G, Wang W, et al. Prevalence of non-syndromic orofacial clefts: based on 15,094,978 Chines perinatal infants. Oncotarget [Internet]. 2018 Mar 2 [cited 2020 May 2];9(17):13981-90. Available at: https://www .ncbi.nlm.nih.gov/pmc/articles/PMC5862631/

9. Impellizzeri A, Giannantoni I, Polimeni A, Barbato E, Galluccio G. Epidemiological characteristic of orofacial clefts and its associated congenital anomalies: retrospective study. BMC Oral Health [Internet]. 2019 Dec 23 [cited 2020 May 2];19(1):290. Available at: https://bmcoralhealth 
.biomedcentral.com/articles/10.1186/s12903 -019-0980-5

10. Kummet CM, Moreno LM, Wilcox AJ, Romitti PA DeRoo LA, Munger RG, et al. Passive smoke exposure as a risk factor for oral clefts-A large international population-based study. Am J Epidemiol [Internet]. 2016 May 1 [cited 2020 May 2];183(9):834-41. Available at: https://www.ncbi .nlm.nih.gov/pmc/articles/PMC4851990/

11. Sabbagh HJ, Hassan MHA, Innes NPT, Elkodary HM, Little J, Mossey PA. Passive smoking in the etiology of non-syndromicorofacial clefts: A systematic review and meta-analysis. PLoS One [Internet]. 2015 Mar 11 [cited 2020 May 2];10(3):e0116963. Available at: https://www .ncbi.nlm.nih.gov/pmc/articles/PMC4356514/

12. Nicoll R. Environmental contaminants and congenital heart defects: a re-evaluation of the evidence. Int J Environ Res Public Health [Internet]. 2018 Oct [cited 2020 May 2];15(10):2096 Available at: https://www.ncbi.nlm.nih.gov/pmc/ articles/PMC6210579/

13. Rappazzo KM, Warren JL, Meyer RE, Herring $\mathrm{AH}$, Sanders AP, Brownstein NC, et al. Maternal residential exposure to agricultural pesticides and birth defects in a 2003 to 2005 North Carolina birth cohort. Birth Defects Res A Clin Mol Teratol [Internet]. 2016 Apr [cited 2020 May 2];106(4):240-9. Available at: https://onlinelibrary wiley.com/doi/full/10.1002/bdra.23479

14. Ward MH, Jones RR, Brender JD, de Kok TM, Weyer PJ, Nolan BT, et al. Drinking water nitrate and human health: an updated review. Int J Environ Res Public Health [Internet]. 2018 Jul 23 [cited 2020 May 2];15(7):1557. Available at: https:// www.mdpi.com/1660-4601/15/7/1557

15. Angulo-Castro E, Acosta-Alfaro LF, Guadron-Llanos AM, Canizales-Román A, González-lbarra F, Osuna-Ramírez I, et al. Maternal risk factors associated with the development of cleft lip and cleft palate in Mexico: a case-control study. Iran J Otorhinolaryngol [Internet]. 2017 Jul [cited 2020 May 2];29(93):189-95. Available at: https://www .ncbi.nlm.nih.gov/pmc/articles/PMC5554809/

16. Taboada Lugo N, Herrera Martínez M, Algora Hernández A, Noche González G, Noa Machado $\mathrm{M}$. Conglomerados espacio-temporales de defectos del tubo neural y niveles maternos de alfafetoproteína en Villa Clara (2011-2015). Rev Cubana Obst Ginecol [Internet]. 2016 [cited 2020 May 2];42(4). Available at: http:// revginecobstetricia.sld.cu/index.php/gin/article/ view/110. Spanish.

17. National Statistics Bureau (CU) [Internet] Havana: National Statistics Bureau (CU); c2021. Cuba y sus territorios. Villa Clara [Internet]. 2018 [cited 2020 May 2]. Available at: http://www.onei .gob.cu/mapa/provincia/villa-clara. Spanish.

18. Rivera C, Arenas Márquez MJ. Bases ambientales y genéticas de las fisuras orofaciales: Revisión. J Oral Res [Internet]. 2013 Mar 21 [cited 2020 May 2];2(1):35-41. Available at: https:// www.researchgate.net/profile/Cesar_Rivera/ publication/272925939_Bases_ambientales_y geneticas de las fisuras orofaciales Revision/ links/5525ceea0cf25d66dc9465b8.pdf. Spanish.

19. Taboada Lugo N. Factores epigenéticos involucrados en el origen de defectos congénitos relacionados con la deficiencia materna de ácido fólico y otros micronutrientes. Acta Med Centro [Internet]. 2019 Jul-Sep [cited 2020 May 2];13(3):439-54. Available at: https://www.med graphic.com/pdfs/medicadelcentro/mec-2019/ mec193q.pdf. Spanish.

20. Gili JA, Poletta FA, Giménez LG, Pawluk MS, Campaña $\mathrm{H}$, Enrique Castilla $\mathrm{E}$, et al. Descriptive analysis of high birth prevalence rate geographical clusters of congenital anomalies in South America. Birth Defects Res A Clin Mo Teratol [Internet]. 2016 Apr [cited 2020 May
2];106(4):257-66. Available at: https://online library.wiley.com/doi/full/10.1002/bdra.23481

21. Agbenorku P. Orofacial clefts: a worldwide review of the problem. ISRN Plastic Surgery [Internet]. 2013 [cited 2020 May 2]:Art ID 348465 Available at: https://www.hindawi.com/journals/ isrn/2013/348465

22. Campos Charris FM, Díaz Galindo MJ, Gil Lizcano FG, Mendoza Castro M, González-Bernal MA. Evaluación de guías de manejo para pacientes con labio y/o paladar hendido. Rev Cubana Estomatol [Internet]. 2019 [cited 2020 Dec 20];56(3). Available at: http://scielo.sld.cu/ pdf/est/v56n3/1561-297X-est-56-03-e1863.pdf. Spanish.

23. Garmendía Hernández G, Felipe Garmendía AM Vila Morales D. Propuesta de una metodología de tratamiento en la atención multidisciplinaria del paciente fisurado labio-alveolo-palatino. Rev Cubana Estomatol [Internet]. 2010 [cited 2020 Dec 20];47(2):143-56. Available at: http://scielo .sld.cu/pdf/est/v47n2/est03210.pdf. Spanish.

24. Herrera MM. Cohorte de malformaciones congénitas y discapacidad cognitiva en la atención genética comunitaria en Villa Clara. XL Premio Anual de la Salud. Havana: Ministry of Public Health (CU); 2015. p. 41. Spanish.

25. Roblejo Balbuena H, Marcheco Teruel B. Genetics and genomic medicine in Cuba. Mol Genet Genomic Med [Internet]. 2017 May [cited 2020 May 2];5(3):196-201. Available at: https://www ncbi.nlm.nih.gov/pmc/articles/PMC5441404/

26. Pan American Health Organization. Clasificación estadística internacional de enfermedades y problemas relacionados con la salud. 10ma Revisión. Edición de 2018 [Internet]. Washington, D.C.: Pan American Health Organization; 2018 [cited 2020 Dec 20]. Available at: https://www minsa.gob.pe/reunis/data/cie10/volumen 1 -2018.pdf. Spanish.

27. Kulldorff M. SaTScan v7.01 software for the spatial and space-time statistics [Internet]. 2018 [cited 2020 May 2]. Available at: https://www satscan.org

28. Gasca-Sánchez FM, Santos-Guzmán J, Elizondo-Dueñaz R, Mejía-Velázquez GM, RuizPacheco C, Reyes-Rodríguez D, et al. Spatial clusters of children with cleft lip and palate and their association with polluted zones in the Monterrey metropolitan Area. Int J Environ Res Public Health [Internet]. 2019 [cited 2020 May 2];16(14):2488. Available at: https://www.mdp .com/1660-4601/16/14/2488

29. Taboada Lugo N. El consentimiento informado en la práctica asistencial e investigativa de la Genética Clínica. Acta Med Centro [Internet]. 2017 [cited 2020 May 2];11(3):88-100. Available at: https://www.medigraphic.com/pdfs/medicadel centro/mec-2017/mec173m.pdf. Spanish.

30. Declaración de Helsinki. Principios éticos para las investigaciones médicas en seres humanos [Internet]. Ferney-Voltaire (FR): World Medical Association; 2017 Mar 21 [cited 2020 Dec 20]. Available at: www.wma.net/es/policies-post/ declaracion-de-helsinki-de-la-amm-principios -eticos-para-las-investigaciones-medicas-en -seres-humanos/. Spanish.

31. Taboada Lugo N. Consideraciones éticas en el diagnóstico prenatal y el asesoramiento genético. Humanidades Médicas [Internet]. 2017 [cited 2020 May 2];17(1):2-16. Available at: https:// www.medigraphic.com/pdfs/hummed/hm-2017/ hm171b.pdf. Spanish.

32. Jamilian $A$, Sarkarat $F$, Jafari $M$, Neshandar $M$, Amini E, Khosravi S, et al. Family history and risk factors for cleft lip and palate patients and their associated anomalies. Stomatologija [Internet] 2017 [cited 2020 May 2];19(3):78-83. Available at: https://www.researchgate.net/profile/Alireza Gha ssemi2/publication/322578779_Family_his tory_and_risk_factors_for_cleft_lip_and_pa late patients and their associated anomalies/ links/5a75675fa6fdccbb3c059e7e/Family-his tory-and-risk-factors-for-cleft-lip-and-palate -patients-and-their-associated-anomalies.pdf

33. Zamora Linares CE. Prevalencia de malformaciones congénitas asociadas en una población de niños con fisuras del labio y del paladar en Manzanillo, Cuba. Rev Soc Bol Ped [Internet]. 2013 [cited 2020 Dec 20];52(1):3-7. Available at: http://scielo.org.bo/pdf/rbp/v52n1/v52n1 a02 .pdf. Spanish.

34. Cisneros Domínguez G, Castellanos Ortíz B, Romero García LI, Cisneros Domínguez CM. Caracterización clínico epidemiológica de pacientes con malformaciones labiopalatinas. MEDISAN [Internet]. 2013 [cited 2020 Dec 20];17(7):103946. Available at: http://www.redalyc.org/articulo .oa?id=368444994002. Spanish

35. Yang W, Carmichael SL, Shaw GM. Folic acid fortification and prevalence of neural tube defects, orofacial clefts, and gastroschisis in California, 1989 to 2010. Birth Defects Res A Clin Mol Teratol [Internet]. 2016 Dec [cited 2020 May 2];106(12):1032-41. Available at: https://onlineli brary.wiley.com/doi/full/10.1002/bdra.23514

36. Kadir A, Mossey PA, Orth M, Blencowe H, Sowmiya M, Lawn JE, et al. Systematic review and meta-analysis of the birth prevalence of orofacial clefts in low- and middle-income countries. Cleft Palate Craniofac J [Internet]. 2017 Sep [cited 2020 May 2];54(5):571-81. Available at: https:// journals.sagepub.com/doi/pdf/10.1597/15-221

37. Matos Noruegas CT, Borges García T, Viera Delgado GL. Fisuras labioalveólopalatinas en el servicio de Ortodoncia. Rev Cubana Ortod [Internet] 1999 [cited 2020 May 2];14(1):13-7. Spanish. Available at: www.docplayer.es/92199659-Fisu ras-labioalveolopalatinas-en-el-servicio-de - ortodoncia.html. Spanish.

38. Delgado Díaz OL, Lantigua Cruz A, Cruz Martínez G, Díaz Fuentes C, Berdasquera Corcho D, Rodríguez Pérez S. Prevalencia de defectos congénitos en recién nacidos. Rev Cubana Med Gen Integr [Internet]. 2007 JulSep [cited 2020 Dec 20];23(3). Available at: http://scielo.sld.cu/scielo.php?pid=S0864 $-21252007000300007 \&$ script=sci_arttext\&tlng= en. Spanish.

39. Reyes Bacardí K, Roque Fernández D, Rodríguez Lemus Y, López Z, Abreu Alfonso Fernández MA, Moreno Tamayo K. Prevalencia de los defectos congénitos en el municipio Arroyo Naranjo. Periodo 2007-2011. Rev Cubana Genet Comunit. 2013;7(3):17-25. Spanish

40. Torres Iñiguez AT, Heredia Pérez JM, López Domínguez M, Santiesteban González M, Lorenzo Felipe D. Incidencia de fisuras de labios y/o paladar en la Provincia Holguín. 1996-2002. Correo Cient Med Holg [Internet]. 2007 Jan-Mar [cited 2020 Dec 20];11(1). Available at: https:// www.imbiomed.com.mx/articulo.php?id=48163. Spanish

41. Corona-Rivera JR, Bobadilla-Morales L, CoronaRivera A, Peña-Padilla C, Olvera-Molina S, Orozco-Martín MA, et al. Prevalence of orofacial clefts and risks for nonsyndromic cleft lip with or without cleft palate in newborns at a university hospital from West Mexico. Congenit Anom (Kyoto) [Internet]. 2018 Jul [cited 2020 May 2];58(4):117-23. Available at: https://onlinelibrary.wiley.com/doi/ epdf/10.1111/cga.12276

42. Butali A, Adeyemo WL, Mossey PA, Olasoji HO, Onah II, Adebola A, et al. Prevalence of orofacial clefts in Nigeria. Cleft Palate Craniofac J [Internet]. 2014 May [cited 2020 May 2];51(3):320-5. Available at: https://journals.sagepub.com/doi/ pdf/10.1597/12-135

43. Pawluk MS, Campaña $H$, Rittler M, Poletta FA Cosentino VR, Gili JA, et al. Individual depriva- 
tion, regional deprivation, and risk for oral clefts in Argentina. Rev Panam Salud Publica [Internet]. 2018 Feb 19 [cited 2020 May 2];41:e110. Available at: https://www.scielosp.org/article/ rpsp/2017.v41/e110/

44. Wang M, Meng R, Wang Z, Liu D, Huang H, Kang $C$, et al. Prevalence of oral clefts among live births in Gansu Province, China. Int J Environ Res Public Health [Internet]. 2018 Feb 23 [cited 2020 May 2];15(2):380. Available at: https://www .mdpi.com/1660-4601/15/2/380

45. Neogi SB, Singh S, Pallepogula DR, Pant $H$, Kolli SR, Bharti P, et al. Risk factors for orofacial clefts in India: a case-control study. Birth Defects Res [Internet]. 2017 Oct 2 [cited 2020 May 2];109(16):1284-91. Available at: https://onlineli brary.wiley.com/doi/pdf/10.1002/bdr2.1073

46. Taboada Lugo N. Papel del ácido fólico, zinc y cobre en la prevención primaria de los defectos congénitos. Rev Cubana Med Gen Integ [Internet]. 2016 [cited 2020 May 2];32(4). Available at: http://www.revmgi.sld.cu/index.php/mgi/article/ view/167. Spanish.

\section{THE AUTHORS}

Noel Taboada-Lugo (Corresponding author: noeltl@infomed.sld.cu), physician with dual specialties in family medicine and clinical genetics, and a master's degree in comprehensive child health. Villa Clara Provincial Medical Genetics Center. Associate professor, Medical University of Villa Clara, Santa Clara, Cuba. https://orcid .org/0000-0002-1254-8087

Manuela Herrera-Martínez, medical geneticist with a doctorate in medical sciences. Full professor and senior researcher, Medical University of Villa Clara, Biomedical Research Unit, Genetic Epidemiology Laboratory, Santa Clara, Cuba. https://orcid.ord/0000-0002-6556-2771
Geni Hernández-González, physician with dual specialties in family medicine and epidemiology. Provincial Health Surveillance Department, Santa Clara, Cuba. https://orcid.org/0000-0003 -3596-3969

Hartley Ledesma-Hernández, professor specializing in technical and professional education, Provincial Health Surveillance Department, Santa Clara, Cuba. https://orcid.org/0000-0001 $-6797-6743$

Submitted: July 13, 2020

Approved for publication: March 15, 2021

Disclosures: None 